Karolina Klimkiewicz (다 https://orcid.org/0000-0002-3684-8404

Dolnośląska Szkoła Wyższa we Wrocławiu

Honorata Cierpisz 그 https://orcid.org/0000-0002-1328-4490

Dolnośląska Szkoła Wyższa we Wrocławiu

\title{
ROZWÓJ ZJAWISKA MOBBINGU W MIEJSCU PRACY W WARUNKACH POLSKICH - IMPLIKACJE DLA PRACY SOCJALNEJ
}

\begin{abstract}
The development of mobbing in the workplace in Polish conditions - implications for social work

The current understanding of the concept of mobbing, its tactics and methods used by mobbers, as well as the legal status, scale and effects of mobbing in the workplace in Poland, compared with other European Union countries were characterized. The summary also discusses the reasons for the persistence of this phenomenon in our country, with proposals for effective fight to combat it, and even to abolish it.
\end{abstract}

Key words: mobbing, mobbing in the workplace, social work

\section{Wprowadzenie}

Mobbing jest zjawiskiem coraz głośniejszym w Polsce, choć nadal niedocenianym. $\mathrm{Z}$ danych statystycznych wynika, że zdarza się coraz częściej i nie jesteśmy usatysfakcjonowani walką z nim, ze strony instytucji i władz państwa. Spora część pracowników czuje się z jego powodu zagrożona i żyje w nieustannym stresie.

W Polsce od momentu transformacji systemu polityczno-gospodarczego ok. 30 lat temu, intensywnym zmianom ulega struktura własności przedsiębiorstw i rynek pracy. Do tego doszedł światowy kryzys ekonomiczny i duże bezrobocie. Od pracowników wymaga się wszechstronności i dyspozycyjności, często nawet po godzinach pracy i w weekendy. Mimo wprowadzania aktualnie wolnych niedziel i innych wcześniejszych przepisów regulujących czas wolny pracownika, w Polsce ludzie nadal bywają wykorzystywani 
w pracy (Pasztelańska 2016). Rosnące do niedawna bezrobocie zmuszało ich do godzenia się na nieuczciwość i wyzysk. Nic dziwnego, że w takich warunkach zjawisko mobbingu mogło się swobodnie rozwijać. Rynek pracy zmienia się jednak ostatnio z powodu przyspieszającej gospodarki i rosnącego braku rąk do pracy, co daje nadzieję na poprawę sytuacji. W dalszym ciągu wiele organizacji i firm musi jednak dążyć do zachowania konkurencyjności i walczy o przetrwanie na rynku, co sprawia, że pracownicy często pozostają jeszcze pod silną presją. Badania krajów europejskich dowodzą, że zjawisko przemocy w miejscu pracy wciąż się nasila, nosząc niekiedy znamiona epidemii, choć generuje to przecież poważne straty finansowe przedsiębiorstw. Dochodzi bowiem do zachwiania relacji między pracownikami i kadrą zarządzającą, a mobbingowane osoby tracą zdrowie i często muszą przez to wcześniej kończyć karierę zawodową lub idą na długie zwolnienia lekarskie:

Dlatego działania mające na celu wyeliminowanie lub choćby ograniczenie występowania przemocy w miejscu pracy (zjawisko mobbingu jest tu jedną ze składowych) powinno leżeć zarówno w interesie pracownika, organizacji i społeczeństwa (Matuszyński 2004).

Obszar pracy socjalnej nie jest również wolny od mobbingu, a powinien przecież być przestrzenią pozbawioną jakiejkolwiek przemocy, ze względu na formę pracy, jaką się w nim wykonuje. Zawód pracownika socjalnego, a co za tym idzie placówki pomocowe - powinny cieszyć się dużym zaufaniem społecznym. Rola, jaką pełnią pracownicy socjalni, wykracza poza obszar pracy, którą można zamknąć po ośmiu godzinach. Pracownicy socjalni często towarzyszą swoim klientom w życiu codziennym, w sytuacjach najtrudniejszych. Pracownik socjalny wykazuje się swoją wiedzą oraz znajomością wielu przepisów i rozporządzeń. Wielokrotnie to pracownik socjalny jako pierwszy rozpoznaje symptomy przemocy u ofiar i sprawców. Nadaje bieg procedurom pomocowym wszelkiego rodzaju, dla swoich klientów. Tym bardziej trudno zrozumieć, dlaczego właśnie w branży, w której powinno być bezpiecznie, tak nie jest i osoby, które pomagają, same stają się ofiarami przemocy swoich przełożonych? Czy kolokwialnie mówiąc, „najciemniej pod latarnią"?

A być może problem leży głębiej? Już na etapie studiów, często do opisania społeczeństwa używa się skojarzenia, jakoby społeczeństwo było niczym organizm. Gdy jeden organ zawodzi, cały holistyczny system również (Szacki 2006: 40). W życiu codziennym często o tym zapominamy i zachowujemy się tak, jakby różne nasze role nie nachodziły się i nie przenikały. Jak komórki w ciele jedna wpływa na drugą. Nasze życie społeczne, rodzinne, zawodowe wymusza na nas konkretne zachowanie, spełnianie norm i zasad odgórnie ustalonych, żeby cała maszyna czy organizm funkcjonowały poprawnie.

Gdy mówimy o zjawisku mobbingu, to należy mieć świadomość, że to nie jest tylko i wyłącznie sprawa personalna, problem odnosi się do konkretnej jednostki (choć przede wszystkim jej to dotyczy), lecz wokół całej organizacji (Walczak, Kozak 2020). Właśnie dlatego należy zastanowić się nad tym, jaką skalę przybrał mobbing w Polsce. 
Czy należy bić na alarm? Czy obecne prawo służące jego zwalczaniu i zapobieganiu jest wystarczające? Czy pracownicy placówek pomocowych są odpowiednio przygotowani do rozpoznawania symptomów mobbingu i jego konsekwencji? Czy wskazane byłyby jakieś zmiany w tych aspektach? Powyższe pytania, jak również inne im podobne, wymagają odpowiedzi, zwłaszcza biorąc pod uwagę implikacje dla pracy socjalnej.

\section{Pojęcie, cechy oraz taktyki mobbingu}

Termin „mobbing” wywodzi się z języka angielskiego od wyrazu mob, czyli 'tłum', 'natłok', 'banda'. Z kolei w łacinie koresponduje ze słowem mobilis, czyli 'ruchomy'. Czasem używa się też terminu bullying pochodzącego od angielskiego słowa bully, które oznacza 'tyrana' dla słabszych, 'znęcać się,' 'terroryzować,' 'zmuszać siłą' (Matuszyński 2004). Amerykanie używają również słowa harassment, czyli 'nękanie.' Terminu „mobbing” jako pierwszy użył szwedzki naukowiec Peter-Paul Heinemann na początku lat 80. XX wieku, odnosząc go najpierw ogólnie do zachowań w różnych grupach społecznych, na przykład w miejscu pracy, szkole, na wyższej uczelni, w rodzinie oraz w innych możliwych wspólnotach i stowarzyszeniach. Twórca definicji mobbingu Peter-Paul Heinemann zdefiniował psychoterror w pracy, jako „wrogą i nieetyczną komunikację pomiędzy osobami pozostającymi ze sobą w relacji zależności” dodając, że „działania te zdarzają się co najmniej raz w tygodniu, przez co najmniej pół roku i skutkują psychicznym, psychofizycznym i społecznym wyczerpaniem" (Davenport, Schwartz, Elliot 1999). Stosujący terror, czyli mobber, regularnie używa przy tym wobec ofiary przynajmniej jednego z aż 45 wyszczególnionych przez Heinza Leymanna zachowań, zaszeregowanych do 5 kategorii:

1. działania zakłócające proces komunikacji,

2. ataki na relacje społeczne,

3. działania mające na celu osłabienie reputacji pracownika,

4. działania podważające pozycję zawodową pracownika,

5. bezpośrednie ataki na bezpieczeństwo i zdrowie pracownika (Matuszyński 2004; Godlewska-Werner 2009).

Jeśli chodzi o mobbing w miejscu pracy, to „osoba nękana w miejscu pracy zazwyczaj nie ma możliwości obrony, często jest narażona na ataki zarówno ze strony pracowników, jak i pracodawcy" (Mobbing, Gazeta Prawna.pl). Augustyn Bańka (2000: 323) pisze o warunkach sprzyjających mobbingowi w miejscu pracy i wymienia następujące czynniki:

- autokratyczny styl zarządzania,

- sztywne struktury hierarchii,

- traktowanie pracownika służbowo,

- chaos w zarządzaniu,

- walka o awans,

- strach o pracę. 
Idąc dalej i analizując polski Kodeks pracy, możemy przeczytać, że zgodnie $\mathrm{z}$ art. $943 \$ 2$ polskiego Kodeksu pracy mobbing oznacza:

wszelkie działania i zachowania dotyczące pracownika lub skierowane przeciwko niemu, polegające na systematycznym i długotrwałym nękaniu lub zastraszaniu, które wywołują zaniżoną ocenę przydatności zawodowej, poniżają lub ośmieszają, izolują lub wykluczają go z zespołu współpracowników (Ustawa z dnia 26 czerwca 1974 r. Kodeks pracy).

Może to przejawiać się poprzez na przykład stałe uwagi negatywne, nieustanną krytykę i wyśmiewanie (publiczne) wykonywanej pracy, wyglądu czy życia prywatnego mobbingowanego pracownika, plotkowanie lub rozprzestrzenianie fałszywych informacji na jej temat, upokarzanie i poniżanie, zniesławianie, obraźliwe żarty i gesty, groźby i zastraszanie, społeczne izolowanie danej osoby, unikanie rozmów z pracownikiem, zmuszanie go do wykonywania prac bezsensownych, poniżej jego umiejętności i godności osobistej lub przerastających jego możliwości i kompetencje, zakaz robienia przerw w pracy, przymus zostawania w pracy po godzinach (często nawet bez płacenia za nadgodziny), utrudnianie wykonywania pracy oraz pomniejszanie kompetencji. Celem sprawcy jest możliwie maksymalne zaszkodzenie i zepsucie opinii ofierze, a ostatecznie jej degradacja ze stanowiska, eliminacja z grona pracowników i zwolnienie z pracy. Działania mobbingowe wywołują u prześladowanego pracownika pogorszenie osiągów i wydajności pracy oraz poczucia bezpieczeństwa, tworząc narastający lęk przed utratą zatrudnienia (Mobbing, Gazeta Prawna.pl). W rezultacie u ofiary mobbingu często rozwijają się zaburzenia psychofizyczne na przykład nerwice, zaburzenia adaptacyjne, traumy, depresje, zespół stresu pourazowego (PTSD), bezsenność, zespół jelita drażliwego (Zarządzanie zasobami ludzkimi - Mobbing, Encyklopedia Governica).

Definicji mobbingu jest wiele, wszystkie podkreślają jednak, że „są to działania niewłaściwe, długotrwale, systematycznie i bezpodstawnie naruszające godność i integralność psychiczną i fizyczną" (Hirigoyen 2003: 11; Bechowska-Gebhardt, Stalewski 2004: 11). Ze względu na kierunki mobbingu w zhierarchizowanych strukturach organizacyjnych, wyróżnia się też: mobbing prosty zwany poziomym/horyzontalnym (osoba mobbująca i ofiara są na tym samym poziomie, czyli na przykład współpracownicy) oraz mobbing ukośny (osoba mobbująca i mobbowana są na różnych poziomach) dzielony na mobbing pionowy wstępujący (pracownicy prześladują szefa) i zstępujący/wertykalny mobbing zwierzchnika (szef prześladuje pracowników) (Mobbing, Gazeta Prawna.pl). Wyszczególniono też mobbing czynny (ograniczanie możliwości podejmowania własnych decyzji i obarczanie nadmierną odpowiedzialnością) i bierny (lekceważenie pracownika poprzez brak poleceń, pomijanie w awansach) (Zarzadzanie zasobami ludzkimi - Mobbing, Encyklopedia Governica). Mobbing może ponadto stanowić działanie bezpośrednie/ kontaktowe (ofiara i mobber są ze sobą w kontakcie bezpośrednim) albo pośrednie (ofiara jest jedynie narażona na skutki nieetycznych działań mobbera) (Matuszyński 2004). Należy też odróżnić mobbing od łamania tzw. zasady równego traktowania w zatrudnieniu (Kodeks Pracy - polskie prawo pracy. Stan prawny: marzec 2018 r.). 


\section{Skala mobbingu w Unii Europejskiej}

Mobbing jest zjawiskiem powszechnym, choć nie zawsze uświadomionym. Dyskusje toczą się głównie w odniesieniu do skali tego zjawiska (Wysokie koszty mobbingu, Wprost.pl 2013). Przykładowo, statystyki z badań przeprowadzonych w 2007 roku w USA wykazały, że na mobbing bardziej narażone są kobiety (aż 57\%), a mężczyźni częściej są mobberami (60\%). Jeśli natomiast to kobieta okazuje się mobberem, wtedy zwykle jej ofiarami są inne kobiety (71\%). Z badania amerykańskiego wynikało również, że osoby czarnoskóre były częściej prześladowane (46\%), w porównaniu z białymi (33,5\%), a na samym końcu znaleźli się Azjaci (30,6\%) (Zarządzanie zasobami ludzkimi - Mobbing, Encyklopedia Governica). Z kolei raport z badań robionych w 1998 roku przez Europejską Fundację do Spraw Poprawy Warunków Życia i Pracy z siedzibą w Dublinie wykazał, że „odsetek pracowników doświadczających mobbingu w krajach UE wynosi: 16,3\% w Wielkiej Brytanii, 10,2\% w Szwecji, 9,9\% we Francji, 9,4\% w Irlandii, 7,3\% w Niemczech, 5,5\% w Hiszpanii, 4,8\% w Belgii, 4,7\% w Grecji i 4,2\% we Włoszech" (Matuszyński 2004; Kłos 2002: 2).

Kolejne większe badania z zakresu i skali mobbingu w krajach UE, przeprowadziła Europejska Fundacja do Spraw Poprawy Warunków Życia i Pracy wespół z Międzynarodową Organizacją Pracy na początku lat dwutysięcznych nowego XXI wieku. Badania te pominęły jednak kraje, które do UE weszły w maju 2004 roku, w tym Polskę. Przemoc w miejscu pracy wykazano wtedy na poziomie (wg kolejności malejącej) (Matuszyński 2004): Finlandia 15\%, Holandia 14\%, Wielka Brytania 14\%, Szwecja 12\%, Belgia 11\%, Francja 10\%, Irlandia 10\%, Dania 8\%, Niemcy 7\%, Luksemburg 7\%, Austria 6\%, Hiszpania 5\%, Grecja 5\%, Włochy 4\%, Portugalia 4\%. W sumie, największy mobbing odnotowano w krajach Europy Północnej (Finlandia, Holandia, Wielka Brytania), a najmniejszy w krajach śródziemnomorskich. Ogólnie wykazano też, że w krajach UE średnio ok. 9\% pracowników jest poddawanych działaniom mobbingowym, przy czym zjawisko to dotyka ok. 10\% pracujących zawodowo kobiet i ok. 7\% mężczyzn. Jeśli natomiast chodzi o poszczególne sektory gospodarki, okazało się, że mobbing w krajach UE kształtuje się następująco wg kolejności malejącej (Matuszyński 2004): 1) administracja publiczna i służby mundurowe $14 \%, 2$ ) edukacja i służba zdrowia 12\%, 3) hotelarstwo i gastronomia $12 \%, 4)$ transport i komunikacja 12\%,5) handel hurtowy i detaliczny 9\%,6) branża nieruchomości (budowa, kupno, sprzedaż) 7\%, 7) przemysł wytwórczy i górnictwo $6 \%, 8$ ) budownictwo 5\%, 9) usługi finansowe 5\%. Ogólnie omawiane badanie wykazało wyższe ryzyko występowania mobbingu w sektorze publicznym, w porównaniu z prywatnym, choć dotąd przeważały i często nadal przeważają opinie przeciwne. Jakie są przyczyny tej dziwnej dla wielu zależności? „Badacze uważają, że tendencja ta związana jest z mniejszymi możliwościami zmiany pracy u osób zatrudnionych w sektorze publicznym, niż prywatnym” (Matuszyński 2004). Można też jednak dodać, że prywatni przedsiębiorcy są nastawieni na zysk, więc dbają o jakość pracy. Natomiast w instytucjach i przedsiębiorstwach państwowych/publicznych kadra zarządzająca nie jest motywowana tym, że złe warunki pracy generują mniejszy zysk. 
Na koniec warto też przytoczyć raport Światowej Organizacji Pracy ILO dowodzący, że „od 40 do 90\% kobiet doświadcza molestowania w ciągu swojego życia zawodowego”. Ważny jest też raport sekretarza generalnego ONZ stwierdzający, że „w Europie którejś $\mathrm{z}$ form molestowania seksualnego w miejscu pracy doświadcza od 40 do 50\% kobiet" (Bratkowska 2013).

Wyżej przytoczone dane pokazują, że zdarzenia przemocowe określane mianem mobbingu mogą na pierwszy rzut oka wydawać się rzadkie. Mobbing dopiero jednak od niedawna stał się przedmiotem badań i analiz statystycznych oraz regulacji prawnych w krajach UE. Akty prześladowania w miejscu pracy zostały też uznane za poważne i można je ścigać jako przestępstwo z urzędu (Mozolewski 2016). Mimo to nadal często jest tak, że sprawy takie są przysłowiowo „zamiatane pod dywan”, a ofiary zastraszane i akty mobbingu nie są w rezultacie nigdzie zgłaszane ani oficjalnie odnotowane w statystykach. Nadal prowadzi się jednak coraz doskonalsze badania i ankiety statystyczne mające na celu kompleksowe określanie realnej skali tego zjawiska, a także jego trafniejsze definiowanie oraz opracowywanie najskuteczniejszych metod przeciwdziałania i regulacji prawnych.

\section{Mobbing w Polsce}

W naszym kraju zjawisko przemocy w miejscu pracy zauważono i zaczęto badać dopiero od niedawna.

Według raportu Szykany w miejscu pracy przeprowadzonego przez CBOS w 2014 roku (Mobbing w Polsce, InfoPraca.pl 2014; Szykany w miejscu pracy - Komunikat $z$ badań CBOS nr 109/2014). Wynika z niego, że mobbing w Polsce jest spotykany dość często, bo aż $17 \%$ pracowników doświadczyło takich szykan w ciągu pięciu ostatnich lat (2009-2014, w sumie ponad 2 mln osób), a 5\% z nich przyznało się, że było to częste. Natomiast szykany równoległe ze strony kolegów i koleżanek z pracy okazały się rzadsze, niż ze strony kadry zarządzającej - w $8 \%$ przypadków (ich ofiarą ze strony swoich współpracowników padł co 12. pracownik). Ponadto:

blisko połowa badanych wskazywała też na bezzasadną krytykę, upokarzanie, podważanie autorytetu, obrażanie określeniami pejoratywnymi lub wulgarnymi, głośne obgadywanie, psychiczne znęcanie się. Okazuje się więc, że wbrew danym PIP i liczbom spraw sądowych nękanie ma miejsce na gigantyczną skalę, tylko nie jest zgłaszane instytucjom i nie prowadzi do żadnych konsekwencji (Szumlewicz 2018b).

We wspomnianym raporcie CBOS podano też, że nawet jeśli pracownicy nie padają ofiarą mobbingu, to jednak obserwują to zjawisko w swoich firmach. Przykładowo szykanowanie innego pracownika przez kadrę zarządzającą widział co czwarty pracownik (24\%), a $17 \%$ zaobserwowało też akty znęcania się i prześladowania wśród współpracowników. 
W sumie badania CBOS wykazały, że łącznie aż 40\% pracowników w Polsce doświadczyło jakichkolwiek form mobbingu. W porównaniu $\mathrm{z}$ badaniami przeprowadzonymi przez CBOS 12 lat wcześniej w 2002 roku, poziom mobbingu uległ w Polsce małemu zmniejszeniu, na przykład spadek o 3\% zdarzeń pozbawiania premii lub nagrody i spadek o $12 \%$ braku wynagrodzenia za nadgodziny. Dla porównania, Europejska Fundacja na rzecz Poprawy Warunków Życia i Pracy z Dublina podała, że w krajach UE mobbing był wtedy stosowany wobec $12 \%$ pracowników (Wysokie koszty mobbingu, Wprost.pl 2013).

$\mathrm{Z}$ nielicznych badań naukowych wynika, że sprawcami mobbingu wobec kobiet w Polsce są z reguły inne kobiety $(41,24 \%)$, a dopiero potem mężczyźni (34,02\%). Natomiast mobbing wobec mężczyzn stosują przede wszystkim inni mężczyźni $(51,85 \%)$, choć wynik ten może być błędny, bo mężczyźni nawet anonimowo nie lubią przyznawać się, że bywają gnębieni przez kobiety. Badania ujawniły też, że kobiety są częściej mobbingowane przez jedną osobę (54,64\%), natomiast mężczyźni przez 2 do 4 osoby (53,09\%) (Godlewska-Werner 2009). Dane innych badaczy czy instytucji polskich wskazują jednak brak związku mobbingu z płcią mobbera.

Skalę mobbingu na polskim rynku pracy przedstawiają też dane zbierane przez Ogólnopolskie Stowarzyszenie Antymobbingowe - OSA, które prowadzi kartotekę zdarzeń mobbingowych w Polsce od początku swojego istnienia, tj. od 2002 roku. OSA powstało w październiku $2001 \mathrm{roku}$, z powodu rosnących szykan w miejscach pracy oraz braku jakichkolwiek uregulowań prawnych i pomocy w tej sprawie. Stowarzyszenie to udziela więc profesjonalnej pomocy pracownikom poszkodowanym w skutek mobbingu w Polsce (prawnej i psychologicznej), a także pomaga tworzyć środowiska pracy wolne od przemocy. Dane Stowarzyszenia OSA również:

potwierdzają istnienie mobbingu, wskazują na duże zainteresowanie zjawiskiem oraz konieczność świadomej walki z problemem. (...) Najczęściej zgłaszanymi działaniami mobbingowymi jest podważanie reputacji i utrudnianie kontaktów interpersonalnych. W większości sytuacji mobberami są przełożeni bez względu na płeć i działający pojedynczo. Natomiast ofiarami są głównie kobiety zatrudnione w instytucjach państwowych (Godlewska-Werner 2009).

Wedle danych z OSA, nie ma jednak reguły odnośnie do płci sprawców mobbingu, mobberzy za to najczęściej działają samodzielnie.

Badania Delikowskiej prowadzone w latach 2002-2003 wskazały, że „mobbing dotyka głównie ludzi z wykształceniem wyższym magisterskim (52,1\% kobiet i 36,3\% mężczyzn) oraz średnim technicznym w przypadku mężczyzn (22,6\%) i średnim zawodowym w przypadku kobiet (11,8\%)" (Delikowska 2003). Zjawisko to przydarza się też częściej kobietom pracującym w sektorze publicznym (60,5\%) i mężczyznom w sektorze prywatnym $(63,7 \%)$. Na to, że ofiarami w głównej mierze są kobiety (panie stanowią niemal $76 \%$ ogółu zgłaszających się do stowarzyszenia), wskazują również dane pochodzące z Ogólnopolskiego Stowarzyszenia Antymobbingowego - OSA. Z kolei znaczną grupę osób zgłaszających się po pomoc do Stowarzyszenia OSA stanowią 
też osoby zatrudnione w sektorze państwowym, w porównaniu z sektorem prywatnym. Najliczniejszą grupą ofiar są pracownicy handlu, marketingu i usług (ok. 25\%), szkolnictwa (ok. 35\%) oraz instytucji samorządowych (ok. 22\%). Mobbing sygnalizowany w OSA dotyczy też głównie prześladowań wobec jednej osoby (87,7\% w 2004 roku, $83,3 \%$ w 2003 roku i 84,8\% w 2002 roku) (Godlewska-Werner 2009).

W 2011 roku Ogólnopolskie Porozumienie Związków Zawodowych przeprowadziło Ankietę o przestrzeganiu praw pracowniczych i doświadczeń $z$ dyskryminacją oraz mobbingiem i molestowaniem seksualnym w miejscu pracy, którą wypełniły 4652 osoby. Wykazano, że 93,3\% badanych wie, co to jest mobbing i potrafi odróżnić go od innych zachowań, $43 \%$ badanych przyznało, że w pracy jest mobbing, a $60,3 \%$ wie, gdzie w razie czego szukać pomocy. Mimo że ankieta była anonimowa, na wiele pytań pracownicy nie chcieli jednak odpowiadać, prawdopodobnie z obawy o pracę (Ostrowska, Michcik 2014: 8-11).

Dane o przemocy i mobbingu w miejscach pracy między innymi w Polsce, można też znaleźć w cyklicznie odbywającym się Europejskim Badaniu Warunków Pracy, autorstwa Eurofound. Piąta edycja tego badania miała miejsce w 2010 roku. Analizie poddano wtedy 35 krajów europejskich, w tym 28 państw członkowskich UE. Łącznie ankietę wypełniło niemal 44 tys. osób, w tym ponad 36 tys. w samej UE. Wykazano przy tej okazji, że w krajach UE „ok. 11\% pracowników zetknęło się z przemocą werbalną podczas wykonywania swojej pracy. Co 20. badany doświadczył gróźb lub upokarzania, zaś blisko $2 \%$ stało się obiektem niepożądanego zainteresowania seksualnego". W omawianej ankiecie Eurofound z 2010 roku ponad 4\% pracowników z krajów UE przyznało się też do narażenia na mobbing w miejscu pracy w ciągu ostatniego roku, a niecałe $2 \%$ na przemoc fizyczną. Polska w badaniu tym wypadła lepiej, znajdując się poniżej średniej europejskiej. Okazało się bowiem, że nieco mniej, bo tylko ok. $1 \%$ respondentów wskazywało u nas na narażenia na przemoc fizyczną w pracy w ciągu roku, 7,9\% pracowników doświadczyło przemocy słownej, $2,4 \%$ doznało gróźb/upokarzania, a zaledwie $1,5 \%$ było narażonych na niechciane zainteresowanie i zachowania o podłożu seksualnym (w tym mniej niż $0,5 \%$ na typowe molestowanie seksualne) (Mozolewski 2016). W badaniach ogólnoeuropejskich zdarzenia określane mianem mobbingu w miejscu pracy mogą wydawać się raczej rzadkie. Warto jednak podkreślić, że duża grupa ludzi nie chce się przyznawać do takich prześladowań, a ankiety te nie obejmują wszystkich mieszkańców Polski, co umniejsza ich wiarygodność.

Na czym najczęściej polegają szykany ze strony pracodawcy lub kadry zarządzającej w Polsce? Przeważnie jest to:

odmowa udzielenia urlopu, trudności ze skorzystaniem ze zwolnienia lekarskiego, powierzanie zadań, których pracownik nie potrafił zrobić, bo nie był należycie przygotowany, krytykowanie wykonania zadań, straszenie zwolnieniem, stosowanie złośliwych uwag i docinków, zmuszanie do zostawania w pracy po godzinach bez wynagrodzenia, pozbawienie nagrody lub premii bez powodu (Mobbing w Polsce, InfoPraca.pl 2014). 
Działania mobbingowe zgłaszane w Ogólnopolskim Stowarzyszeniu Antymobbingowym - OSA rozkładają się natomiast w następujący sposób: najczęściej jest to pogwałcenie prawa pracy, a potem również ocenianie pracy w sposób fałszywy i ubliżający, groźby, podawanie w wątpliwość umiejętności zawodowych, ignorowanie, wyzwiska, utrudnianie wykonywania zadań (Godlewska-Werner 2009).

Osoba mobbingowana bez wątpienia przechodzi pewien rodzaj tortur, w których mobber stosuje metody manipulacji od najbardziej subtelnych i niezauważalnych przez ofiarę po najbardziej drastyczne, powodujące u ofiary izolację społeczną, jej autodeprecjację, poczucie krzywdy, bezsilności i odrzucenia przez współpracowników, a w konsekwencji silny stres i choroby somatyczne i psychiczne (Bechowska-Gebhardt, Stalewski 2004). Wiąże się to z kolei z ograniczonym funkcjonowaniem, niemożnością wykonywania swoich obowiązków zawodowych i rodzinnych. Zaburzenie funkcjonowania rodziny przekłada się na niezliczoną ilość komponentów wpływających na kształt i jakość zarówno życia społecznego, jak i egzystencji poszczególnych jednostek tkwiących w obszarze dysfunkcyjnym (Trojanowski, Tworek, Wawrzyniak-Kostrowicka 2012). Zaburzenia funkcjonowania rodziny stanowią wyzwanie dla systemów pomocowych. Pracownicy Socjalni, Asystenci Rodzin, Kuratorzy, Koordynatorzy Pieczy Zastępczej wszyscy pracujący z rodziną już w pierwszym wywiadzie powinni pytać swoich klientów o pracę i warunki w jakich pracują. Atmosfera w jakiej pracujemy ma fundamentalne znaczenie dla naszego funkcjonowania nie tylko w pracy, ale i poza pracą.

\section{Prawodawstwo polskie}

Choć Polska weszła do Unii Europejskiej dopiero w maju 2004 roku, to już jako czwarty kraj europejski od razu na wstępie wprowadziła regulacje prawne przeciwdziałające mobbingowi - nowelizacja Kodeksu Pracy z 14 listopada 2003 roku, która weszła w życie w dwóch terminach: 1 stycznia 2004 roku i z dniem uzyskania przez Polskę członkostwa w UE. Przepisy polskie odnoszą się przy tym zarówno do samego zjawiska mobbingu (art. $94^{3} \$ 1$, w którym ustawodawca zobowiązuje pracodawcę do przeciwdziałania mobbingowi), jak i do wszelkiego innego prześladowania, rasizmu i dyskryminacji (rozdział II a o nakazie równego traktowania w zatrudnieniu, w tym tępieniu i karalności za przejawy molestowania w art. $18^{3 a} \S 5$ pkt. 2, a także molestowania seksualnego w art. 18 ${ }^{3 a} \$ 6$ ) (Matuszyński 2004).

Według art. $94^{3} \S 2$. polskiego Kodeksu pracy, mobbing oznacza:

działania lub zachowania dotyczące pracownika lub skierowane przeciwko pracownikowi, polegające na uporczywym i długotrwałym nękaniu lub zastraszaniu pracownika, wywołujące u niego zaniżoną ocenę przydatności zawodowej, powodujące lub mające na celu poniżenie lub ośmieszenie pracownika, izolowanie go lub wyeliminowanie z zespołu współpracowników (Ustawa z dnia 26 czerwca 1974 r. Kodeks pracy). 
Osobą dopuszczającą się mobbingu (mobberem) może być przy tym sam pracodawca, osoba zarządzająca zakładem pracy w imieniu pracodawcy, a także zwykły przełożony lub współpracownik/współpracownicy, czy nawet podwładny ofiary. Pracodawcę zobowiązano oczywiście do przeciwdziałania mobbingowi (art. $94^{3} \$ 1 \mathrm{~K} . \mathrm{p}$.), przy czym w art. $94^{3} \$ 3$ K.p. zapisano jego odpowiedzialność za mobbing w miejscu pracy. Pracownik może dzięki temu za utratę zdrowia „dochodzić od pracodawcy odpowiedniej sumy tytułem zadośćuczynienia pieniężnego za doznaną krzywdę" (art. $94^{3} \$ 3$ Kodeksu pracy). Jakie ma to być zadośćuczynienie nie określono już w K.p., więc na podstawie art. 300 K.p. stosuje się w tym względzie właściwe przepisy kodeksu cywilnego (art. 445 K.c. oraz art. 444 K.c.). Pracownik, który ucierpiał z powodu mobbingu może więc „rozwiązać umowę o pracę $\mathrm{w}$ trybie natychmiastowym, bez wypowiedzenia, wskazując mobbing jako przyczynę rozwiązania stosunku pracy” (Mobbing, GazetaPrawna.pl). Dodatkowo, jeśli mobbing był przyczyną rozwiązania umowy o pracę, pracownik ma też „prawo dochodzenia od pracodawcy odszkodowania w wysokości nie niższej niż minimalne wynagrodzenie za pracę" (art. $94^{3}$ Kodeksu pracy), którego górna wysokość nie została w tych przepisach ograniczona (art. $94^{3} \$ 4$ K.p.). Ponadto pracownik, u którego mobbing w miejscu pracy wywołał jakikolwiek rozstrój zdrowia, może również dochodzić od pracodawcy „zadośćuczynienia pieniężnego za doznaną krzywdę” (Ustawa z dnia 26 czerwca 1974 r. Kodeks pracy; Mobbing, Gazeta Prawna.pl).

Pojęcie mobbingu jest nowością w polskim ustawodawstwie dotyczącym prawa pracy, dlatego nie ma wystarczająco jasnych i dobrze wypraktykowanych kryteriów umożliwiających ewidentne rozdzielenie mobbingu od takich atrybutów pracodawcy i przełożonego, jak egzekwowanie poleceń i dyscypliny oraz kształtowanie właściwych postaw i zachowań w pracy (Szewczyk 2012). Co prawda, art. $94^{3}$ K.p. jednoznacznie zobowiązuje pracodawcę do przeciwdziałania mobbingowi, przez co jest on odpowiedzialny za występowanie tego negatywnego zjawiska w miejscu pracy, i to niezależnie od tego, kto jest jego sprawcą, a kto ofiarą. Pracodawca ponosi odpowiedzialność nawet jeśli sam nie zawinił, lecz zrobił to inny pracownik, gdy wykazane zostaną przesłanki prawne potwierdzające odpowiedzialność za cudzy czyn. W praktyce jednak ciężar przedstawienia dowodów $\mathrm{w}$ sprawie oraz udowodnienie występowania mobbingu w sądzie spoczywa wyłącznie na poszkodowanym, a oskarżony mobber nie musi początkowo dowodzić swej niewinności. Sprawy takie są więc szczególnie trudne w sądzie dla poszkodowanych i przeważnie skazane na porażkę. Ponadto, kluczową rolę w tego typu postępowaniach mają też orzeczenia biegłych psychologów, psychiatrów i innych lekarzy, oceniające stopień rozstroju zdrowia wywołanego mobbingiem (Mobbing, Gazeta Prawna.pl). To też rodzi problemy, ponieważ ofiary mobbingu nie myślą zwykle zawczasu, by gromadzić dowody potwierdzające takie szkody w momencie ich zaistnienia. Nawet jeśli osoba nękana dowiedzie jednak swojej krzywdy, to polskie sądy i tak często nie uznają mobbingu. A jeśli nawet ofiara ma szczęście i mobbing zostanie przez sąd uznany, to i tak w polskim ustawodawstwie nie ma zapisów odpowiednio regulujących nieuchronność godnych zadośćuczynien. Wyroki zasądzają zwykle żenująco niskie kary i odszkodowania. Wielu specjalistów i poszkodowanych uważa więc, że ochrona przed 
mobbingiem jest w Polsce de facto przynajmniej częściową fikcją (Guza 2017). Nic zatem dziwnego, że pomimo częstego uskarżania się pracowników na szykany i nękanie ze strony pracodawców, liczba osób decydujących się na dochodzenie swoich praw w sądzie jest u nas bardzo mała.

\section{Zakończenie}

Mobbing w Polsce niezaprzeczalnie istnieje, nasze prawo nie chroni jednak jego ofiar w sposób wystarczający, nierównomiernie obarczając osoby mobbingowane ciężarem dowodzenia tego zjawiska i poniesionych z tego tytułu szkód własnych. Gdy ofiara żąda odszkodowania, musi się też zwolnić z pracy, a jeśli chce zadośćuczynienia, musi przedstawić dowody (jak zaświadczenie lekarskie), że zachowanie mobbera wywołało u niej uszczerbek na zdrowiu, na przykład depresję. Ofiara musi więc dużo sama udowodnić, środki dowodowe są jednak mocno ograniczone (Guza 2017). Nawet jeśli poszkodowany dowiedzie mobbingu i jego złych skutków, to wyroki i tak są niskie i niesatysfakcjonujące. Sądy często nawet nie widzą w tym problemu. Dotychczasowe ustawodawstwo polskie wymaga więc zmian gwarantujących poszkodowanym mobbingiem większe prawa i możliwości, a także sprawiedliwość wyroków i nieuchronność kar dla mobberów (Durniat 2012: 213-222). Przezwyciężanie mobbingu w pracy powinno przy tym postępować dwutorowo:

należy zadbać o właściwe zarządzanie personelem, prowadzić odpowiednią politykę rekrutacyjną, ale też położyć nacisk na regularne szkolenia i konferencje poświęcone zagadnieniom przemocy w pracy. Budując kulturę organizacji, trzeba pamiętać, że muszą cechować ją: otwartość i jawność, a prawo do krytyki i swobodnego wypowiadania się przysługuje każdemu pracownikowi (Matuszyński 2004).

Choć jednak od dłuższego czasu potrzeby te są głośno postulowane, to nadal nie znajdują godnego odzwierciedlenia w dotychczasowych zmianach ustawodawstwa prawnego (Kodeks pracy i inne) (Guza 2017).

Statystyki prowadzone w Polsce ukazują nasz kraj jako oazę, gdzie mało kto bywa nękany przez pracodawcę. W trzech kwartałach 2015 roku Państwowa Inspekcja Pracy otrzymała 1198 skarg na mobbing, z czego tylko 81 uznano za zasadne. W 2015 roku w polskich sądach rejonowych odbywało się 559 spraw, w których wydano 241 wyroków, z których jedynie w 28 przypadkach w całości lub choćby w części uwzględniono roszczenia pracownika (Szumlewicz 2018a). Raport pt. Szykany w miejscu pracy przeprowadzony przez Fundację Centrum Badania Opinii Społecznej CBOS w 2014 roku ujawnił tymczasem, że mobbing w Polsce jest spotykany dość często. Mobbing w pracy potwierdziło aż $17 \%$ badanych, w tym $5 \%$ przyznało, że zdarzenia takie były częste. Natomiast szykan ze strony koleżanek i kolegów z pracy doświadczyło nieco mniej, bo 8\% pracowników. Badania wykazały też, że nawet jeśli pracownicy osobiście nie padają ofiarą mobbingu w pracy, to jednak obserwują takie zachowania. Szykanowanie innego 
pracownika przez szefa widział już co czwarty pracownik (24\%), z kolei aż 17\% widziało przejawy równoległego (wzajemnego) znęcania się wśród pracowników (Szykany $w$ miejscu pracy. Komunikat $z$ badań CBOS nr 109/2014). Zjawisko mobbingu może być nawet większe, ponieważ nie wszyscy poszkodowani chcą przyznać się do prześladowań. W polskich firmach nawet co dziesiąty pracownik może być ofiarą mobbingu (Warszewska-Makuch 2007).

Przejawy mobbingu w Polsce dotyczą głównie:

odmowy udzielenia urlopu, trudności ze skorzystaniem ze zwolnień lekarskich, powierzania zadań, których pracownik nie umiał zrobić, krytykowania wykonania zadań, straszenia zwolnieniem, stosowania złośliwych uwag i docinków, zmuszania do pracy po godzinach bez wynagrodzenia, pozbawiania nagród i premii bez powodu (Mobbing w Polsce, InfoPraca.pl 2014).

Konflikty w pracy są przy tym źródłem dużych kosztów z powodu między innymi „Zmniejszenia motywacji i zaangażowania pracowników, spadku wydajności pracy, wzrostu absencji, kosztów ewentualnych odszkodowań i strat wizerunkowych". Przykładowo w Niemczech straty gospodarki z tego powodu ocenia się na kilkanaście mld euro rocznie. Amerykański badacz i mediator Daniel Dana wskazał, że „w ponad 65\% takich przypadków, spadek wydajności i jakości pracy wynika właśnie z napięć w stosunkach między pracownikami, a nie z braku kwalifikacji i motywacji do pracy" (Wysokie koszty mobbingu, Wprost.pl 2013). Mobbingowani wpadają w nerwice i depresje. Zakład Ubezpieczeń Społecznych potwierdza złą kondycję psychiczną naszych obywateli z tego tytułu, skutkującą aż 9,5 mln dniami zwolnień lekarskich w połowie 2016 roku (Szumlewicz 2018b).

W Polsce mobbing jest zjawiskiem powszechnym, badanym jednak rzadko i niechętnie. Utrzymuje się niska świadomość takich zachowań u pracowników i pracodawców. Przyczyny mobbingu zwykle leżą wewnątrz organizacji, na przykład złe zarządzanie (kierownik autorytarno-despotyczny, liberalny styl kierowania), kiepska organizacja pracy, zbyt sztywna struktura, osłabienie więzi interpersonalnych i brak zaufania, niezdrowa rywalizacja wśród pracowników (tzw. wyścig szczurów), brak umiejętności zarządzania konfliktami i polityki antymobbingowej. Choć w Polsce odpowiedzialna była za to również do niedawna zła sytuacja polityczno-gospodarcza, w tym przede wszystkim wysokie bezrobocie oraz niedoskonałe prawo pracy (Bechowska-Gebhardt 2004; Godlewska-Werner 2009). Wiele osób uważa jednak tego typu działania za normalny i dopuszczalny rygor w pracy. Menedżerowie deklarują zwykle, że mobbing jest im obcy, po szkoleniach właściwego zarządzania kadrą aż 80\% z nich deklaruje jednak, że stosowali lub nadal stosują motywację negatywną i/lub sami też byli jej poddawani w karierze zawodowej. Niezbędna w likwidacji i przeciwdziałaniu mobbingowi, poza poprawą prawa i jego stosowania jest więc również właściwa profilaktyka zawodowa w formie szkoleń wszystkich pracowników i pracodawcy. Niezbędne jest też postępowanie zgodnie z procedurami i standardami kodeksów etyki oraz piętnowanie i karanie mobberów. Pozwoli to również uniknąć pracodawcom odpowiedzialności prawnej. 
Przełożeni i podwładni muszą znać właściwe sposoby komunikacji oraz egzekwowania swoich prawa i obowiązków (Durniat 2012: 213-222; Wysokie koszty mobbingu, Wprost.pl 2013). Jak zauważa Mozolewski, „w myśl zasady, że lepiej zapobiegać niż leczyć, kluczowe jest więc zbudowanie kultury zero tolerancji dla przemocy" (Mobbing i dyskryminacja, https://badaniahr.pl/), co nie jest wcale łatwym procesem, zwłaszcza że właściwa kultura zarządzania i stosunków w miejscu pracy jest często tworzona i ustalana przez całe lata, a jej wprowadzanie i kształtowanie to bardzo złożony i szeroko zakrojony proces, złożony z:

1. oceny norm i wartości, jakie przejawiają pracownicy, w szczególności wyłonienia subkultur/grup pracowników narażonych na zjawisko przemocy;

2. wprowadzenia procedur i polityki przeciwdziałania przemocy i postępowania w razie jej wystąpienia - reguły powinny przy tym zawierać definicję przemocy, określać sposób raportowania jej przypadków i określać konsekwencje wobec sprawców. Zasady powinny być spisane, dostępne i dobrze znane pracownikom;

3. szkoleń menedżerów i pracowników szeregowych, obejmujących zarówno nowo zatrudnionych pracowników, jak i osoby pracujące od dawna. Szkolenia takie powinny eksponować zasadę całkowitego braku przyzwolenia na przemoc oraz udzielać informacji o sposobach radzenia sobie z problemami w pracy, na przykład za pomocą programów EAP (ang. Employee Assistance Program, czyli Program Wsparcia Pracowników);

4. stosowania procedur wobec przemocy, co powinno być na bieżąco monitorowane i oceniane. Ważne, aby działania pracodawcy nie były odbierane jako „siłowe” bądź karzące. Podstawową zasadą jest opieranie się na zachętach oraz wyrażanie postawy szacunku wobec pracowników (Mozolewski 2016).

Agata Bechowska-Gebhard i Tadeusz Stalewski wykonali katalog cech organizacji, w których mobbing w ogóle się nie pojawia. Wykazali, że nie notuje się go w instytucjach, w których stosuje się jasne, sprawiedliwe i wyraźnie określone zasady między innymi: 1) systemy zarządzania, 2) podział kompetencji i zadań, 3) jawne sposoby i zasady podejmowania decyzji, 4) systemy ocen pracowników oraz odpowiednie procedury rekrutacji, selekcji i awansowania personelu, 5) systemy i zasady wynagradzania, 6) swobodny przepływ informacji, 7) podmiotowe traktowanie pracowników oraz branie pod uwagę przez kierownictwo ich opinii i oczekiwań, 8) poszanowanie godności osoby ludzkiej przez pracodawcę i jego kierownictwo (kadrę zarządzającą, menedżerską), 9) dużą kulturę osobistą u osób zajmujących stanowiska kierownicze/ menedżerskie, 10) inwestuje się w pracowników, zachęca ich do zdobywania wiedzy i podnoszenia kwalifikacji. Osoby zajmujące się polityką personalną w przedsiębiorstwie muszą posiadać właściwą i wyczerpującą wiedzę w tym zakresie. Z kolei właściciel/pracodawca, jak i jego kierownictwo musi mieć odpowiednio dużą wiedzę i doświadczenie praktyczne w zarządzaniu zmianami i konfliktami (Bechowska-Gebhardt, Stalewski 2004: 62-63; Matuszyński 2004). Kadra zarządzająca musi też mieć opracowany (przez siebie lub działy HR czy PR) Program Działań Antymobbingowych (tzw. polityka antymobbingowa, w tym Komisja Antymobbingowa) i/lub Program 
Wsparcia Pracowników (Employee Assistance Program), uwzględniający charakter organizacji oraz podnoszenie kwalifikacji w zakresie kierowania konfliktami etycznymi. Pracodawca musi też zezwolić na działanie pracowniczych związków zawodowych i promować etyczne zachowanie w instytucji (tzw. dobre praktyki, czyli propagowanie właściwych wzorców i zachowań, nagradzanie budujących przykładów i stawianie ich za wzór, stanowcze potępianie i karanie zachowań nieetycznych). W ramach aktywnej edukacji menedżerskiej i zawodowej, pracodawca powinien też rozważyć możliwość cyklicznego przeprowadzania tzw. treningów wrażliwości etycznej, z omawianiem pozytywnych i negatywnych działań i zachowań (ang. case studies) (Zbiegień-Maciąg 2002: 217-229; Matuszyński 2004).

Temat choć bardzo trudny, pozwala zobaczyć, że placówki pomocowe, gdzie pracują pracownicy socjalni nie są wolni od tego typu przemocy, a to rodzi dużą potrzebę uświadomienia społeczeństwa.

Ponadto według Najwyższej Izby Kontroli (2019) organizacja i warunki pracy pracowników socjalnych nie pozwalają w pełni na skuteczną realizację ich zadań w zakresie pomocy społecznej. Z ogólnopolskiego badania ankietowego przeprowadzonego przez NIK w 2019 roku - w którym wzięło udział 4206 z 19610 pracowników socjalnych, czyli niemal jedna czwarta wszystkich zatrudnionych (to największe tego typu badanie środowiska pracowników socjalnych w Polsce), wynika, że po pierwsze pracowników socjalnych jest zbyt mało, przez co pracownicy socjalni są przeciążeni pracą. Wyposażenie i narzędzia pracy pracowników socjalnych nie wystarczają do sprawnego wykonywania zadań. Praca pracownika socjalnego, zarówno w biurze, jak i w terenie wiąże, się z wieloma zagrożeniami (pomówienia $25 \%$, groźby $17 \%$, wyzwiska $14 \%$, poniżanie $32 \%$ ), do tego pracownicy socjalni mają zbyt niskie wynagrodzenia nieadekwatne do wykonywanych zadań i niekonkurencyjne na rynku pracy oraz małe wsparcie psychofizyczne, na przykład w postaci superwizji czy psychologa (NIK 2019, Organizacja $i$ warunki pracy pracowników socjalnych $w$ gminach).

Biorąc to wszystko pod uwagę, trzeba pamiętać, że niełatwo obecnie o stabilną i bezpieczną pracę oraz o fakcie, $w$ jak trudnym położeniu jest ofiara, która w tym przypadku z góry podlega pewnego rodzaju władzy. Szef - w tym kontekście sprawca w zakładzie pracy ma pewnego rodzaju władzę nad swoich pracownikiem i trudno zidentyfikować, gdzie ta władza się kończy, a gdzie zaczyna przemoc. Dlatego też tak trudno przeciwdziałać mobbingowi. Chcemy również podkreślić, że naszym celem nie jest stygmatyzowanie obszaru pracy socjalnej, tylko głośne powiedzenie, że jeśli dzieje się coś złego czy niepokojącego, musimy bić na alarm i stawać w obronie swoich praw, dyskutować i poddawać głębokiej refleksji po to, żeby takich działań było jak najmniej, a miejsce pracy było bezpieczne, przynajmniej ze strony naszych współpracowników i przełożonych. 


\section{Bibliografia}

Bańka A. (2000). „Psychologia organizacji. Gdańskie Wydawnictwo Psychologiczne, Gdańsk.

Bechowska-Gebhardt A., Stalewski T. (2004). Mobbing. Patologia zarządzania personelem. Difin, Warszawa.

Bratkowska M. (2013). Niemoralne propozycje. „Tygodnik Wprost”, 38, 1595; https://www.wprost. pl/tygodnik/416728/Niemoralne-propozycje.html (dostęp: 15.03.2018).

Davenport N., Schwartz D.R., Elliot P.G. (1999). Mobbing: Emotional Abuse in the American Workplace. Civil Society Publishing, Ames, Iowa.

Delikowska K. (2003). Raport z badań na temat działań mobbingowych w miejscu pracy, Publikacja Wspólnoty Roboczej Związków Organizacji Socjalnych. „Społecznik”, 7: 1-27.

Durniat K. (2012). Prewencja i przeciwdziałanie mobbingowi w polskich organizacjach. „Współczesne Zarządzanie", 4: 213-222.

Godlewska-Werner D. (2009). Mobbing w polskich przedsiębiorstwach. Instytut Pracy i Spraw Socjalnych, 13.02.2009; http://www.wnp.pl/wiadomosci/mobbing-w-polskich-przedsiebiorstwach,-5252_1_0_1.html (dostęp: 13.03.2018).

Guza Ł. (2017). Samotność nękanych. W Polsce ochrona przed mobbingiem jest fikcja. „Dziennik.pl”, 15.01.2017; http://gospodarka.dziennik.pl/praca/artykuly/540195,mobbing-prawo-dyskryminacja-walka-z-mobbingiem.html (dostęp: 15.03.2018).

Hirigoyen M.F. (2003). Molestowanie w pracy. W drodze, Poznań.

Kłos B. (2002). Mobbing. Kancelaria Sejmu - Biuro Studiów i Ekspertyz. Informacja, nr 941, Warszawa. Kodeks Pracy - polskie prawo pracy. Stan prawny: marzec 2018 r.; http://kodeks-pracy.org/I-przepisy-ogolne/rowne-traktowanie-w-zatrudnieniu (dostęp: 13.03.2018).

Matuszyński W. (2004). O źródłach i sposobach przezwyciężania mobbingu w organizacji. Referat wygłoszony na VIII Ogólnopolskiej Konferencji „Etyka w życiu gospodarczym” 13 maja 2004 r. w Łodzi, zorganizowanej przez Salezjańską Wyższą Szkołę Ekonomii i Zarządzania w Łodzi, publ. na stronie Krajowego Stowarzyszenia Antymobbingowego we Wrocławiu; http://www.mobbing.most.org.pl/publikacja_3.htm (dostęp: 11.03.2018).

Mobbing i dyskryminacja; https://badaniahr.pl/ (dostęp: 11.03.2018).

Mobbing w Polsce. „InfoPraca.pl”, 8.11.2014; http://weblog.infopraca.pl/2014/11/mobbing-polsce/ (dostęp: 16.03.2018).

Mobbing, w: Encyklopedia. „Gazeta Prawna.pl”; http://www.gazetaprawna.pl/encyklopedia/ praca/hasla/333815,mobbing.html (dostęp: 10.03.2018).

Mozolewski M. (2016). Przemoc w pracy. Praktyczne porady dla menedżerów, działów HR i innych pracowników. „Rynekpracy.pl Sedlak \& Sedlak”; https://rynekpracy.pl/artykuly/ przemoc-w-pracy-praktyczne-porady-dla-menedzerow-dzialow-hr-i-innych-pracownikow (dostęp: 15.03.2018).

NIK (2019). Organizacja i warunki pracy pracowników socjalnych w gminach; nik.gov.pl, https:// www.nik.gov.pl/aktualnosci/organizacja-i-warunki-pracy-pracownikow-socjalnych-w-gminach.html (dostęp: 27.03.2020).

Ostrowska M., Michcik A. (2014). Mobbing - istota, przyczyny, przeciwdziałanie. „Ergonomia”, 6: 8-11. 
Pasztelańska J. (2016). Zaharowany jak Polak. Pracujemy do granic wytrzymałości, bo chcemy? „Gazeta Prawna.pl”; http://serwisy.gazetaprawna.pl/praca-i-kariera/artykuly/970525,zaharowani-polacy-zaharowani-polacy.html (dostęp: 11.03.2018).

Szacki J. (2006). Historia myśli socjologicznej. Wydanie nowe. Wydawnictwo Naukowe PWN, Warszawa.

Szewczyk H. (2012). Mobbing w stosunkach pracy. Zagadnienia prawne. Wydawnictwo Naukowe Scholar, Warszawa.

Szumlewicz P. (2018a). Mobbing po polsku. Nękanie na gigantyczna skalę bez konsekwencji. „Dziennik.pl”; http://gospodarka.dziennik.pl/praca/artykuly/567168,szumlewicz-o-mobbingu-po-polsku.html (dostęp: 17.03.2018).

Szumlewicz P. (2018b), Mobbing to masowe zjawisko w Polsce. Dlaczego więc nie istnieje w statystykach? „Forsal.pl”; http://forsal.pl/artykuly/1098901,mobbing-to-masowe-zjawisko-w-polsce-dlaczego-wiec-nie-istnieje-w-statystykach.html (dostęp: 18.03.2018).

Szykany w miejscu pracy. Komunikat z badań CBOS nr 109/2014. Fundacja Centrum Badania Opinii Społecznej, Warszawa: 1-13; http://www.cbos.pl/SPISKOM.POL/2014/K_109_14. PDF (dostęp: 16.03.2018).

Trojanowski P., Tworek I., Wawrzyniak-Kostrowicka M. (2012). Asystent Rodziny jako innowacyjny instrument pomocy na tle mechanizmów przeciwdziałających wykluczeniu społecznemu rodzin. Leader-Great Publishers, Wydawnictwo Fundacji Emanuel, Łódź.

Ustawa z dnia 26 czerwca 1974 roku. Kodeks pracy (Dz.U. 1974 nr 24 poz. 141).

Walczak A., Kozak M. (2020). Mobbing w organizacji pomocowej jako przykład patologii zarzadzania. Studium przypadku. „Górnośląskie Studia Socjologiczne. Seria Nowa”, 11: 183-199.

Warszewska-Makuch M. (2007). W polskich firmach co dziesiaty pracownik może być ofiara mobbingu. „GazetaPrawna.pl”; http://biznes.gazetaprawna.pl/artykuly/4181,w-polskich-firmach-co-dziesiaty-pracownik-moze-byc-ofiara-mobbingu.html (dostęp: 18.03.2018).

Wysokie koszty lobbingu (2013). „Wprost.pl”; https://www.wprost.pl/392540/Wysokie-koszty-mobbingu (dostęp: 16.03.2018).

Zarzadzanie zasobami ludzkimi - Mobbing. Encyklopedia Governica; https://www.governica. com/Mobbing (dostęp: 14.03.2018).

Zbiegień-Maciąg L. (2002). Etyka w zarządzaniu organizacją, w: J. Dietl, W. Gasparski (red.). Etyka biznesu. Wydawnictwo Naukowe PWN, Warszawa: 217-229. 